\title{
JUVENILE AND AGE-SPECIFIC $L r$-GENES OF RESISTANCE TO Puccinia triticina Eriks. IN Triticum aestivum L.: REALITY OR CONDITIONALITY
}

\author{
L.G. Tyryshkin, V.G. Zakharov, V.V. Syukov \\ N.I. Vavilov Research Institute of Plant Industry, RAAS, St. Petersburg 190000, Russia \\ e-mail: tyryshkinlev@rambler.ru \\ Received April 9, 2012 \\ S u m mary
}

In accordance with current conception the genes of resistance of soft wheat to leaf rust divided into genes of juvenile and age resistance. The authors studied the virulence of monopustular isolates of disease agent to juvenile and adult plants of isogenic lines of the Thatcher variety and wheat varieties with different $L r$ genes of resistance. It was shown, that $\operatorname{Lr} 12, \operatorname{Lr} 13, L r 34, L r 35, L r 46, L r 48$ and $L r 49$ genes, relating to genes of age resistance, determine the resistance to some agent' $s$ isolates also in juvenile plants. The $\operatorname{Lr} 1, \operatorname{Lr} 10, \operatorname{Lr} 14 a, \operatorname{Lr} 15, \operatorname{Lr} 20, \operatorname{Lr} 23, \operatorname{Lr} 26, \operatorname{Lr} 34, \operatorname{Lr} 36, \operatorname{Lr} 37$ genes, which in set articles were related to genes of juvenile resistance, against individual pathogen isolates manifest properties of juvenile resistance genes, and the beginning of their expression in different leaf level depends on pathogen isolate.

Keywords: wheat, leaf rust, juvenile resistance, adult resistance, genes for resistance.

Leaf rust resistance genes $\mathrm{Lr}$ are a group of oligogenes that provide resistance of wheat (Triticum aestivum L.) to lear rust Puccinia triticina Erikss. [syn.: P. recondita Roberge: Desm. f. sp. tritici (Erikss.) C.O. Johnston]. There are two groups of leaf rust resistance genes are classified in the literature: juvenile-seedling $L r$ genes are expressed in young plants starting from the $1^{\text {st }}$ leaf, and they provide resistance of plants to individual (or all) clones of leaf rust during a whole ontogenesis; adult-plant $L r$ genes are not expressed in juvenile plants, but they determine resistance to individual (or all) rust genotypes at later ontogeny stages (pre-flag and flag leaf, etc.) (1). Catalogs of R.A. McIntosh et al. (2-6) describe 67 identified $L r$ genes including 59 genes for juvenile resistance and 8 genes for adult resistance ( $L r 12, L r 13, L r 22 a, L r 22 b, L r 35, L r 46, L r 48, L r 49)$. Along with it, genes $L r 34, L r 27+31, L r 37(1)$, and $\operatorname{LrlO}(7)$ are known to provide age-specific resistance to leaf rust.

The available scientific literature contains very little information about the expression of adult resistance genes in juvenile plants, as well as about the juvenile resistance genes that control resistance of plants to particular isolates of $P$. triticina only in later ontogeny stages. For example, it was reported that adult-plant resistance gene $L r 13$ also determines resistance of wheat seedlings to particular isolates of leaf rust, especially at high temperature (2). The study of $P$. triticina isolates collected in the Northern Caucasus revealed differences in the rate of virulence manifested in seedlings and flag leaves of different lines - carriers of different $L r$ genes (8) (assuming it only as preliminary result, because the tested leaf segments were soaked in benzimidazole - the inducer of resistance). Juvenile resistance genes $\operatorname{Lr} 14 b, \operatorname{Lr} 23, \operatorname{Lr} 26$, and $L r 29$ didn't provide resistance to race 77 in seedlings of isogenic lines, but they controlled their leaf rust resistance at later developmental stages (9).

The purpose of this work was testing the hypothesis about conventional division of wheat $L \mathrm{r}$ genes into juvenile and adult resistance genes.

Technique. Monopustular isolates of Puccinia triticina were derived from the pathogen populations collected in the Middle Volga (Samara and Ulyanovsk regions) and maintained on fragments of wheat leaves cv Leningradka. Seeds of near-isogenic wheat lines cv Thatcher with resistance genes $\operatorname{Lr} 1, \operatorname{Lr} 10, \operatorname{Lr} 12, \operatorname{Lr} 13, \operatorname{Lr} 14 a, \operatorname{Lr} 15, \operatorname{Lr} 17, \operatorname{Lr} 20, \operatorname{Lr} 23, \operatorname{Lr} 26, \operatorname{Lr} 32, \operatorname{Lr} 34, \operatorname{Lr} 35, \operatorname{Lr} 36, \operatorname{Lr} 37$, as well as samples with genes $L r 27+31, L r 46, L r 48$, and $L r 49$ were germinated in cuvettes on cotton wool soaked in water. After germination, the seedlings were exposed to constant illumination (light stand, $25001 \mathrm{x}, 20-22^{\circ} \mathrm{C}$ ). Seeds of lines with resistance genes Lr 1, Lr10, Lr14a, Lr15, Lr20, Lr23, Lr26, Lr34, Lr35, Lr36, and Lr37 were sown in boxes with soil and grown to heading in a climate chamber (constant illumination $2500 \mathrm{~lx}, 22^{\circ} \mathrm{C}$ ).

Expression of adult resistance genes in juvenile plants, as well as expression of juvenile resistance genes in adult plants was evaluated in two independent experiments.

In the first experiment, leaf segments of $0,8-1,0 \mathrm{~cm}$ long were cut from seedlings of near-isogenic lines $\mathrm{cv}$ Thatcher with genes $\operatorname{Lr} 10, \operatorname{Lr} 12, \operatorname{Lr} 13, \operatorname{Lr} 34, \operatorname{Lr} 35$, as well as samples with genes $\operatorname{Lr} 27+31, \operatorname{Lr} 46, \operatorname{Lr} 48$, and $\operatorname{Lr} 49$, placed in cuvettes on a cotton wool soaked in benzimidazole aqueous solution $(100 \mathrm{mg} / \mathrm{l})$ and infected with 200 monopustular isolates of the pathogen (10). The cuvettes were covered with glass, placed for 12 hours in darkness and then in a light stand $\left(21^{\circ} \mathrm{C}\right.$, constant illumination 2500 lx). Type of response to the infection was accounted on the $7^{\text {th }}$ day after inoculation according to a scale of E.B. Mains and H.S. Jackson (11): 0 - no symptoms of lesion; 0 - necrosis without pustules; 1 - very small pustules with necrosis of surrounding tissue; 2 medium-sized pustules with chlorosis or necrosis; 3 - pustules of medium and large size without necrosis. The clones that provided 0 response of infected wheat (high degree of resistance, pathogen avirulence) were used to inoculate intact plants of these samples whose response to the infection was evaluated on the $12^{\text {th }}$ day after inoculation using the same scale.

In the second experiment, leaf segments were cut from seedlings of lines with resistance genes $L r 1, \operatorname{Lr} 10, \operatorname{Lr} 14 a, L r 15, L r 20$, $\operatorname{Lr} 23, \operatorname{Lr} 26, \operatorname{Lr} 34, \operatorname{Lr} 36, \operatorname{Lr} 37$, placed in a cuvette on cotton wool soaked with water and infected with monopustular isolates of $P$. triticina. Ten clones virulent in these conditions to an individual line (reaction type 3 ) were used to infect the segments of different leaves placed in water: flag leaf, the $2^{\text {nd }}$ (pre-flag 1 ), $3^{\text {rd }}$ (pre-flag 2), and $4^{\text {th }}$ (pre-flag 3 ) leaves from the top of leaf tier. The response to infection was accounted on the $7^{\text {th }}$ day after inoculation under the scale of E.B. Mains and H.S. Jackson (11).

Results. The rate of monopustular leaf rust isolates avirulent to the plants with resistance genes $\operatorname{Lr} 10, \operatorname{Lr} 12, \operatorname{Lr} 13, \operatorname{Lr} 34, \operatorname{Lr} 35$, $L r 27+31, L r 46, L r 48$ and $L r 49$ in the experiment with leaf segments soaked in benzimidazole, amounted to, respectively, 0,23; 0,18; 0,$13 ; 0,13 ; 0,34 ; 0,40 ; 0,20 ; 0,19 ; 0,19$. Since this substance at the used concentration causes genotype-dependent induction of resistance to leaf rust in wheat (10), the isolates classified as avirulent for plants with a respective resistance gene were used to infect intact juvenile plants. In variants with resistance genes $L r 10, L r 12, L r 13, L r 34, L r 35, L r 27+31, L r 46, L r 48$, and $L r 49$ there were detected, respectively, $16 ; 6 ; 6 ; 10 ; 51 ; 36 ; 18 ; 16$; and 10 avirulent monopustular isolates of the pathogen. In this case, the lines and 
samples with genes $\operatorname{Lr} 10, \operatorname{Lr} 12, \operatorname{Lr} 27+31, \operatorname{Lr} 34, \operatorname{Lr} 35, \mathrm{Lr} 46, \mathrm{Lr} 48, \mathrm{Lr} 49$ manifested 0 type of response, and only the line with $\operatorname{Lr} 13$ exhibited type 2 response. So, these genes earlier known as adult resistance genes may also determine juvenile resistance to particular genotypes of leaf rust pathogen.

In the variant with adult plants' leaves inoculated with monopustular isolates of $P$. triticina virulent for seedlings of the lines with resistance genes $\operatorname{Lr} 1, \operatorname{Lr} 10, \operatorname{Lr} 14 a, \operatorname{Lr} 15, \operatorname{Lr} 20, \operatorname{Lr} 23, \operatorname{Lr} 26, \operatorname{Lr} 34, \operatorname{Lr} 36, \mathrm{Lr} 37$, in all cases it was observed the response of resistance to individual isolates (Table). In other words, genes classified in the scientific literature as capable for juvenile resistance genes were found to provide resistance of adult plants to individual isolates of leaf rust. It has been first shown that pathogen isolate determines the expression of resistance genes in adult plants' leaves of different tiers. Thus, the line with $L r 10$ manifested resistance to different clones of $P$. triticina starting from the $3^{\text {rd }}$ and $2^{\text {nd }}$ leaf from the top of leaf tier, or it was expressed only in flag leaf (Table). The line with $L r 23$ gene showed resistance to most of the studied clones in the $3^{\text {rd }}$ leaf from top of the tier, though in the variant with one of the isolates only flag leaf was resistant to infection.

Types of response to infestation with monopustular isolates of Puccinia triticina in leaves of nearly isogenic wheat lines cv Thatcher with $\mathbf{L r}$ genes for leaf rust resistance.

\begin{tabular}{|c|c|c|c|c|c|}
\hline \multirow{2}{*}{$\begin{array}{l}\text { Number of } \\
\text { clones }\end{array}$} & \multirow{2}{*}{$1^{\text {st }}$ leaf } & \multicolumn{4}{|c|}{ Leaf from the top of leaf tier } \\
\hline & & $4^{\text {th }}$ (pre-flag 3) & $3^{\text {rd }}$ (pre-flag 2) & $2^{\text {nd }}$ (pre-flag 1) & flag \\
\hline \multicolumn{6}{|c|}{ Ge n e $L r l$} \\
\hline 2 & 3 & 3 & 0 & 0 & 0 \\
\hline 8 & 3 & 3 & 3 & 3 & 3 \\
\hline \multicolumn{6}{|c|}{ Ge n e $\operatorname{Lr} 10$} \\
\hline 1 & 3 & 3 & 0 & 0 & 0 \\
\hline 1 & 3 & 3 & 3 & 0 & 0 \\
\hline 2 & 3 & 3 & 3 & 3 & 0 \\
\hline 6 & 3 & 3 & 3 & 3 & 3 \\
\hline \multicolumn{6}{|c|}{ Ge ne $L r 14 a$} \\
\hline 8 & 3 & 3 & 3 & 3 & 0 \\
\hline 2 & 3 & 3 & 3 & 3 & 3 \\
\hline \multicolumn{6}{|c|}{ Ge ne $L r 15$} \\
\hline 1 & 3 & 3 & 0 & 0 & 0 \\
\hline 8 & 3 & 3 & 3 & 3 & 0 \\
\hline 1 & 3 & 3 & 3 & 3 & 3 \\
\hline \multicolumn{6}{|c|}{ G e n e $L r 20$} \\
\hline 1 & 3 & 3 & 3 & 3 & 0 \\
\hline 9 & 3 & 3 & 3 & 3 & 3 \\
\hline \multicolumn{6}{|c|}{ Ge ne $L r 23$} \\
\hline 8 & 3 & 3 & 0 & 0 & 0 \\
\hline 1 & 3 & 3 & 3 & 3 & 0 \\
\hline 1 & 3 & 3 & 3 & 3 & 3 \\
\hline \multicolumn{6}{|c|}{ G e n e $L r 26$} \\
\hline 8 & 3 & 3 & 3 & 0 & 0 \\
\hline 2 & 3 & 3 & 3 & 3 & 3 \\
\hline \multicolumn{6}{|c|}{ Ge n e $L r 34$} \\
\hline 7 & 3 & 3 & 3 & 0 & 0 \\
\hline 2 & 3 & 3 & 3 & 3 & 0 \\
\hline \multirow{2}{*}{\multicolumn{6}{|c|}{ Ge ne $\operatorname{Lr} 36^{3}$}} \\
\hline & & & & & \\
\hline 5 & 3 & 3 & 3 & 3 & 0 \\
\hline 5 & 3 & 3 & 3 & 3 & 3 \\
\hline \multicolumn{6}{|c|}{ G e $\mathrm{n}$ e $L r 37$} \\
\hline 6 & 3 & 3 & 3 & 0 & 0 \\
\hline 4 & 3 & 3 & 3 & 3 & 0 \\
\hline
\end{tabular}

Thus, these findings demonstrate that Lr genes of wheat are just conventionally classified as different groups of juvenileseedling and adult-plant resistance genes, because one gene may show the effect of both these groups depending on genotype of the pathogen. The practical meaning of this fact is that the estimate of leaf rust virulence for seedlings doesn't allow predicting field resistance to leaf rust in wheat samples with genes known from the literature as juvenile resistance genes, because this degree of virulence may largely differ from the rate of lesions observed on leaves of adult plants.

\section{REFERENCES}

1. Kolmer J.A. Genetics of resistance to wheat leaf rust. Annu. Rev. Phytopathol., 1996, 34: 435-455.

2. McIntosh R.A., Yamazaki Y., Devos K.M., Dubcovsky J., Rogers W.J., Appels R. Catalogue of gene symbols for wheat. MACGENE2003 (CD Version). User Manual.

3. McIntosh R.A., Devos K.M., Dubcovsky J., Rogers W.J., Morris C.F., Appels R., Somers D.J., Anderson O.A. Catalogue of gene symbols for wheat: 2007 Supplement. http://wheat.pw.usda.gov/ggpages/wgc/2007upd.html.

4. McIntosh R.A., Yamazaki Y., Dubcovsky J., Rogers W.J., Morris C.F., Somers D.J., Appels R., Devos K.M. Catalogue of gene symbols for wheat 2008. http://wheat.pw.usda.gov/GG2/Triticum/wgc/2008/.

5. McIntosh R.A., Dubcovsky J., Rogers W.J., Morris C.F., Appels R., Xia X.C. Catalogue of gene symbols for wheat: 2009 Supplement. http://www.shigen.nig.ac.jp/wheat/komugi/genes/macgene/supplement2009.pdf.

6. McIntosh R.A., Dubcovsky J., Rogers W.J., Morris C.F., Appels R., Xia X.C. Catalogue of gene symbols for wheat: 2011 Supplement.

http://www.shigen.nig.ac.jp/wheat/komugi/genes/macgene/supplement2011.pdf.

7. Kurbanova P.M. Geneticheskoe raznoobrazie yarovoi myagkoi pshenitsy po effektivnoi vozrastnoi ustoichivosti k listovoi rzhavchine. Avtoreferat kandidatskoi dissertatsii [Genetic Diversity of Soft Spring Wheat with Respect to Efficiency of Adult Leaf Rust Resistance, Extended Abstract of Cand. Sci. Dissertation]. St. Peteburg, 2011.

8. Tyryshkin L.G. Genetika donorov ustoichivosti pshenitsy $k$ listovoi rzhavchine i usovershenstvovanie metodov differentsiatsii populyatsii vozbuditelya. Avtoreferat kandidatskoi dissertatsii [Genetics of Wheat Donors of Leaf Rust Resistance and Improving the Methods for Differentiation of Pathogen Populations, Extended Abstract of Cand. Sci. Dissertation]. Leningrad, 1988.

9. Saini R.G., Gupta A.K., Nand D.A. Expression of some leaf rust resistance genes at different growth stages in wheat against race 77-A. Current Sci., 1986, 85(16): 802-804.

10. Tyryshkin L.G., Kurbanova P.M. Mikologiya i Fitopatologiya, 2009, 43(1): 75-80.

11. Mains E.B., Jackson H.S. Physiological specialization in leaf rust of wheat, Puccinia triticina Erikss. Phytopathology, 1926, 16: 89-120. 